\title{
АНАЛІЗ ЕКСПЛУАТАЦІЙНОЇ СТІЙКОСТІ РЕЙОК НА ЛІНІЯХ ХАРКІВСЬКОГО МЕТРОПОЛТТЕНУ
}

\author{
Кандидати техн. наук В. Г. Вітольберг, Д. О. Потапов, А. С. Малішевська, \\ асист. Н. О. Муригіна
}

\section{ANALYSIS OF OPERATIONAL STABILITY OF THE RAYO ON THE LINES OF THE KHARKOV METROPOLITEN}

\author{
PhD (Tech.) V. H. Vitolberh, PhD (Tech.) D. O. Potapov, PhD (Tech.) A. S. Malishevska, \\ assistant lecturer N. O. Muryhina
}

DOI: https://doi.org/10.18664/1994-7852.184.2019.176427

Статтю присвячено формуванню статистичної бази з метою дослідження факторів, які негативно впливають на технічний стан рейкових ліній. Це необхідно для підвищення безпеки руху $і$ пошуку напрямків зменшення витрат на утримання ліній метрополітену. Формування статистичної бази виконувалося за даними експлуатації трьох головних колій Харківського метрополітену, розгорнута довжина яких складає 74,6 км. Головним показником для визначення терміну служби рейок прийнято було значення пропущеного тоннажу.

Ключові слова: метрополітен, колія, дефекти рейок, вихід рейок, статистична база, план колії.

The article is devoted to the formation of a statistical base for the study of factors that negatively affect the technical state of the rail lines. This is necessary to improve the safety of the movement and to find directions for reducing the cost of maintaining the subway lines. The formation of the statistical base was carried out according to the data of operation of the three main roads of the Kharkiv subway, the length of which is expanded $74.6 \mathrm{~km}$. The main indicator for determining the service life of the rails was the value of the missing tonnage.

It is clear that in this case, it is particularly important to seek methods that reduce the cost of maintaining lines for the possibility of subway operation under conditions of limited resources.

The analysis of damage and deflection rails was performed on the basis of data on the output of rails on all lines of the Kharkiv Metro.

Particularly important is the need to find methods that can reduce the cost of the current maintenance of railways for the possibility of subway operation under conditions of limited resources.

The basis of the research was the results of many years of observations on the work of the rails on the way, numerical studies of the dynamics of the interaction of the path and rolling stock in the metro

One of the ways to reduce the cost of maintaining subway lines is to further explore the factors that negatively affect the life of rails and the development of measures that prevent it.

These studies allowed establishing the main types of defects rails. Their changes depend on the curvature of the sites, and the changes in these defects over time. The data on the distribution of the rails output in the periods 1986-2001 and 2005-2011 as a whole by subway depending on the track plan was obtained. 
In the article an analysis is made which points to the actual problem, namely, the defeat of defects of the contact-fatigue origin of the tracks.

Keywords: underground, track, deflection rails, rail rails, statistical base, track plan.

Вступ. Особливістю метрополітену як міського пасажирського залізничного транспорту $\epsilon$ масовість, регулярність i безпека перевезень. Це вигідно відрізняє його від інших видів міського транспорту.

Враховуючи це, на Харківському метрополітені триває створення нових i розвиток вже існуючих ліній, незважаючи на складні економічні умови.

Цілком зрозуміло, що при цьому особливо важливим стає пошук методів, які надають змогу зменшити витрати на утримання ліній для можливості функціонування метрополітену в умовах обмежених ресурсів.

Аналіз останніх досліджень i публікацій. Питанням термінів служби рейок та виникнення дефектів в умовах метрополітену приділяється увага як в Україні [1-4], так і за кордоном [5], однак для дещо іншої постановки завдання.

Визначення мети та завдання дослідження. Один із напрямків зменшення витрат на утримання ліній метрополітену полягає в додатковому дослідженні факторів, які негативно впливають на термін служби рейок, i розробленні заходів, що запобігають цьому.
Але для цього потрібна відповідна статистична база.

Основна частина дослідження. Дослідження виконувалися на базі даних експлуатації трьох головних колій Харківського метрополітену, розгорнута довжина яких складає 74,6 км. Для скорочення назвемо ці лінії: «X», «C» $\mathrm{i} \ll \mathrm{O} »$.

Загальна розгорнута довжина цих колій складає 74,6 км.

Ширина колій на прямих ділянках та у кривих за радіусом від 400 м складає 1520 мм [6, 7].

На коліях застосовуються рейки типу Р-50, переважна більшість яких виготовлена на металургійному комбінаті «Азовсталь» мартенівським способом.

Як підрейкові опори у тунелях використовуються дерев'яні шпали, а на станціях - дерев'яні напівшпали. Епюра шпал - 1680 шт/км на прямих, та 1840 шт/км - у кривих ділянках колії.

Відомо, що основним показником для визначення терміну служби рейок прийнято значення пропущеного тоннажу $[8,9]$. При досягненні його нормативного значення має проводитися суцільна заміна рейок відповідно до табл. 1.

Таблиця 1

Періодичність заміни рейок від пропущеного тоннажу

\begin{tabular}{|l|c|}
\hline \multicolumn{1}{|c|}{ План лінії } & $\begin{array}{c}\text { Пропущений тоннаж для рейок Р50, } \\
\text { млн т брутто }\end{array}$ \\
\hline Прямі та криві радіусом 1001 м і більше & 550 \\
\hline Криві радіусом 1000-801 м & 500 \\
\hline Криві радіусом 800-651 м & 450 \\
\hline Криві радіусом 650-501 м & 400 \\
\hline Криві радіусом 500-351 м & 325 \\
\hline Криві радіусом менше 350 м & 250 \\
\hline
\end{tabular}


3 метою підвищення надійності колії та безпеки руху поїздів до кожного значення пропущеного тоннажу (див. табл. 1) запропоновано відповідну умову експлуатації для рейок типу Р50 сумарний вихід рейок (шт/км), який не має перевищувати відповідних норм (табл. 2).

Аналіз пошкоджень та дефектів рейок виконувався на підставі даних щодо виходу рейок по всіх трьох лініях метрополітену $(\mathrm{X} », \ll \mathrm{C} » \mathrm{i} \ll \mathrm{O} »)$, які було зібрано за два періоди: перший - з 1986 р. по 2001 р., масив даних склав 632 рейки;

другий - 3 початку 2005 року по березень 2011 р., масив даних склав 763 рейки.

Тому загальний масив даних про вихід рейок для статистичної обробки склав 1395 рейок.

Дані про розподіл виходу рейок у періоди 1986-2001 і 2005-2011 рр. у цілому по метрополітену залежно від плану колії наведено, відповідно, в діаграмах (рис. 1, 2).

Норми виходу рейок Р50 залежно від плану лінії метро

\begin{tabular}{|l|c|}
\hline \multicolumn{1}{|c|}{ План лінії } & Вихід рейок Р50, шт/км \\
\hline Прямі та криві радіусом 1001 м і більше & $4-6$ \\
\hline Криві радіусом 1000-801 м & $4-6$ \\
\hline Криві радіусом 800-651 м & $5-7$ \\
\hline Криві радіусом 650-501 м & $6-8$ \\
\hline Криві радіусом 500-351 м & $7-9$ \\
\hline Криві радіусом менше 350 м & $8-10$ \\
\hline
\end{tabular}

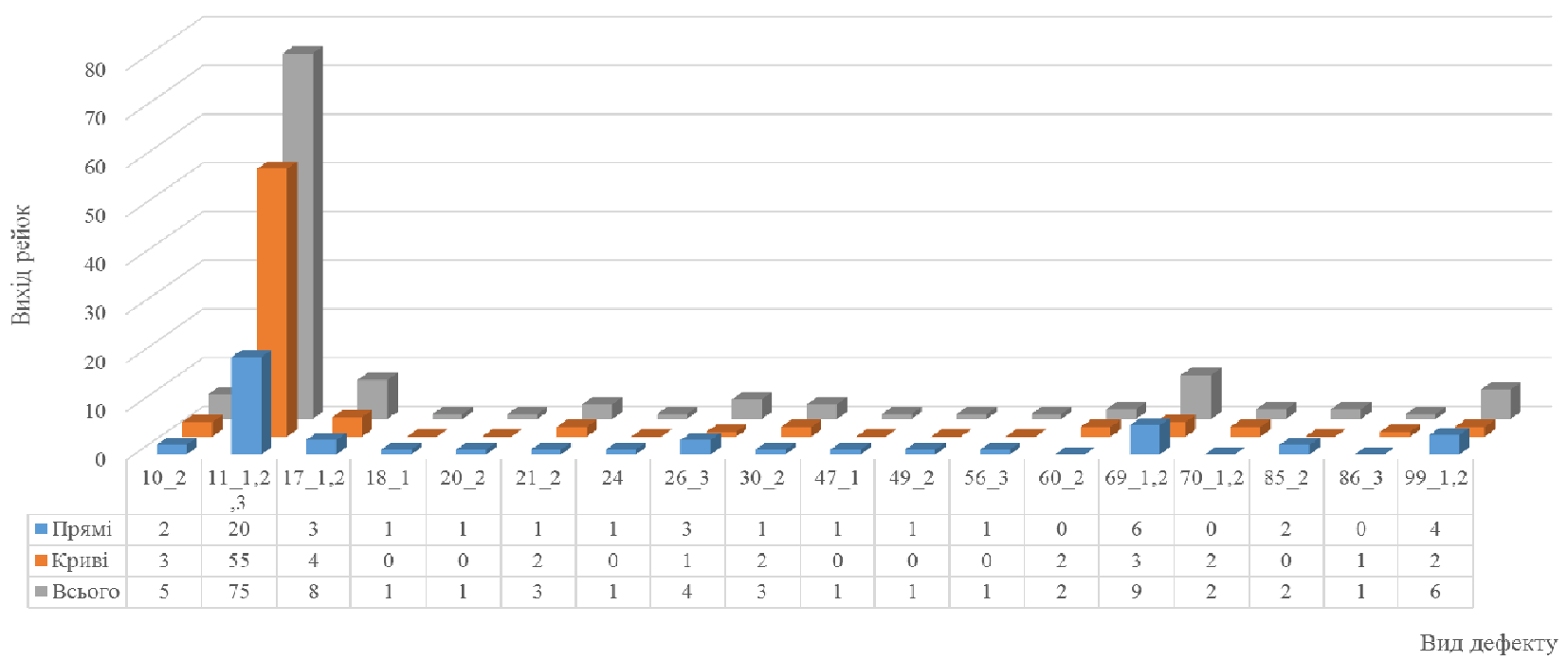

Рис. 1. Загальний вихід рейок по метрополітену в період 1986-2001рр. 


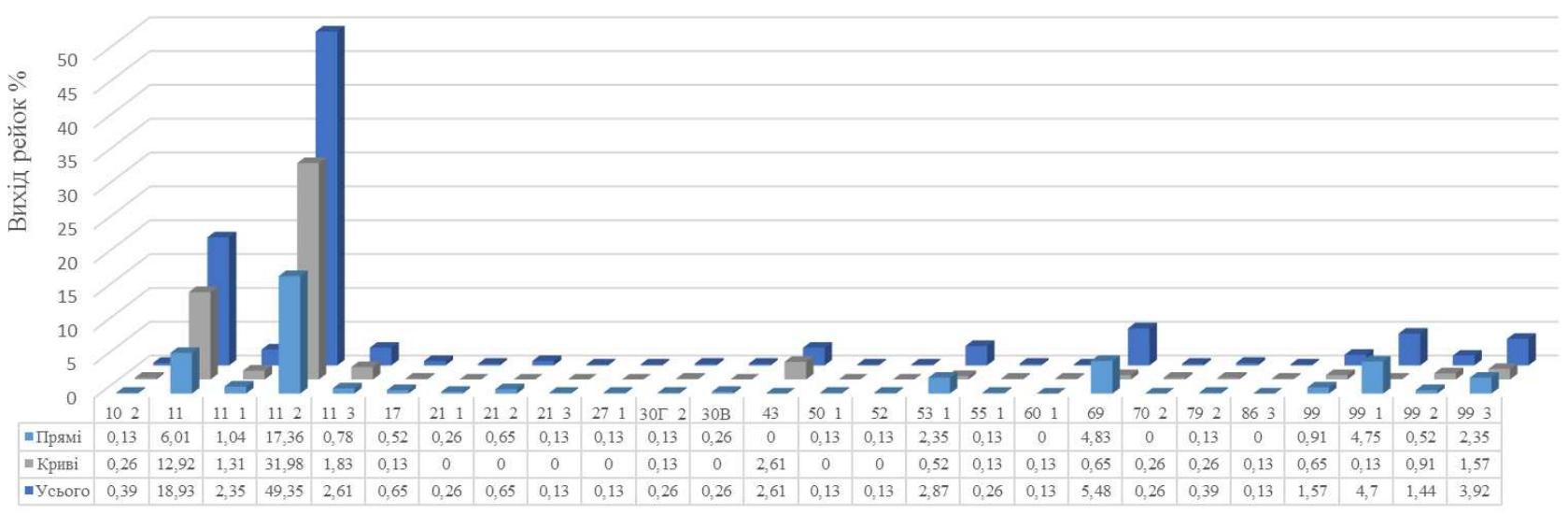

Вид дефекту

Рис. 2. Загальний вихід рейок по метрополітену в період 2005-2011 pp.

При побудові діаграм прямі ділянки колії, а також криві з радіусом більше ніж 1000 м було віднесено до категорії «Прямі», криві менших радіусів - до категорії «Криві».

Робити певні висновки про роботу рейок по лінії «О» в період 1986-2001 pp. не було можливим через відсутність достатнього обсягу статистичних даних. Тому на рис. 1 відображені дані тільки щодо ліній « $\mathrm{X} » \mathrm{i} \ll \mathrm{C} »$.

Основними видами дефектів рейок були дефекти контактно-втомного походження, за кодами 11.1, 11.2, 11.3 (табл. 3), які розвиваються у головці рейки 3 причин недостатньої контактно-втомної міцності рейкової сталі.

Оскільки укладання рейок змінювалося у межах 1977-2008 pр., то масив даних практично містив кілька циклів експлуатаційної роботи рейок як по окремих лініях, так i в цілому по метрополітену. Це дало змогу встановити різні види пошкоджень і дефектів рейок на початковій стадії їх роботи, а також виконати дослідження інтенсивності раптових та поступових відмов у період експлуатації рейок.

Такий диференціальний підхід дає змогу правильно висвітлити роботу рейок 3 урахуванням причин розвитку дефектів та пошкоджень, а також виділити групу найбільш типових дефектів. А це у свою чергу дає можливості для подальшої розробки математичної моделі експлуатаційної надійності рейок залежно від пропущеного тоннажу та кривизни залізничної колії з подальшою обробкою і систематизацією за видами дефектів та пошкоджень.

Чинним документом у колійному господарстві метрополітенів України, який визначає вид дефекту рейок, $\epsilon$ «Класифікація i каталог дефектів i пошкоджень рейок на залізницях України». За даними рис. 1 і 2 можна побачити, що найбільш характерними дефектами рейок на Харківському метрополітені виявлені ті, що наведені у табл. 3.

Висновки. Завдяки зробленому аналізу пошкоджень та дефектів рейок у Харківському метрополітені можна побачити, що найпоширенішими є дефекти за кодами 11.1-3, а саме викришування металу на бічній робочій викружці внаслідок недостатньої контактно-втомної міцності металу.

Кількість таких дефектів складала у 1986-2011 рр. до 75 \%. При цьому основна частина цих дефектів за кодом 11 виникає в кривих ділянках колії. Це призводить до посиленого зносу бічної грані головки зовнішньої рейки і розвитку дефектів контактновтомного походження першої групи. 
Найбільш характерні дефекти рейок на Харківському метрополітені

\begin{tabular}{|l|l|}
\hline \multicolumn{1}{|c|}{ Найменування дефекту і основні причини } \\
його появи та розвитку
\end{tabular}

На другому місці за частотою виникнення $\epsilon$ корозійно-втомні тріщини в підошві рейок у зонах зварних стиків та поза нею. Виникненню таких дефектів, окрім дії рухомого складу, сприяє підвищена вологість в умовах колії метрополітену.

Дефекти у вигляді зминання головки внутрішньої рейки в кривій, які свідчать, про перевантаження внутрішньої нитки, не перевищують $3 \%$. Виникнення цих дефектів пов'язане 3 надмірним підвищенням рівня зовнішньої нитки або зі зменшенням швидкості руху відносно розрахункових величин, згідно 3 якими влаштовувалось існуюче підвищення.

У діаграмах це не відображено, але важливо підкреслити, що спостерігається тенденція до збільшення виходу рейок за цими видами дефектів зі зменшенням радіуса колії. Це цілком зрозуміло, оскільки при зменшенні радіуса кривої дія бічних зусиль на головку рейки збільшується.

Проведений аналіз вказує на існуючу проблему ураження колій дефектами контактно-втомного походження, а також порушує питання визначення методів для iï розв' язання.

\section{Список використаних джерел}

1. Darenskiy A., Potapov D., Tuley Y., Bugaets N., Malishevskaya A. Revisiting the reasons for contact fatigue defects in rails. MATEC Web of Conferences. 2017. Vol. 116. 03001. 
2. Йосифович Р. М. Наукове обгрунтування i практичне вирішення проблеми підвищення експлуатаційного ресурсу рейок Київського метрополітену в 2013-2016 рр.: автореф. дис... канд. техн. наук. Київ : ДЕТУТ, 2016. 26 с.

3. Даніленко Е. І., Йосифович Р. М., Олійник О. А., Сорока О. О. Дослідження впливу динамічних колісних навантажень, вантажонапруженості і швидкостей руху поїздів на міцність, стійкість і строки служби рейок, скріплень та інших елементів ВБК. Збірник наукових пращь Державного економіко-технологічного університету транспорту. Сер. Транспортні системи і технології. Київ, 2013. № 22. С 10-20.

4. Taraf M. et al. Numerical analysis for predicting the rolling contact fatigue crack initiation in a railway wheel steel. Tribology International. 2010. № 3(43). C. 585-593.

6. Инструкция по текущему содержанию пути и контактного рельса метрополитенов. Москва, 1995. 160 с.

7. Правила технічної експлуатації Харківського та Дніпропетровського метрополітенів. Харків, 2005. 222 c.

8. Технічні вказівки на експлуатацію рейок та елементів стрілочних переводів КП «Харківський метрополітен». Харків, 2012. 7 с.

9. Класифікація і каталог дефектів і пошкоджень елементів стрілочних переводів та рейок залізниць України. Київ: ТОВ «Інпрес», 2013. 194 с.

Вітольберг Володимир Геннадійович, канд. техн. наук, доцент кафедри колії та колійного господарства Українського державного університету залізничного транспорту. E-mail: ppx_xiit@kart.edu.ua.

Потапов Дмитро Олександрович, канд. техн. наук, доцент кафедри колії та колійного господарства

Українського державного університету залізничного транспорту. E-mail: ppx_xiit@kart.edu.ua.

Малішевська Аліна Сергіївна, канд. техн. наук, асистент кафедри колії та колійного господарства Українського державного університету залізничного транспорту. Тел. 0930201843. E-mail: kttolik@gmail.com.

Муригіна Надія Олександрівна, асистент кафедри колії та колійного господарства Українського державного

університету залізничного транспорту. E-mail: ppx_xiit@kart.edu.ua.

Vitolberh Volodymyr Hennadiiovych, PhD (Tech.), Assistant Professor, Department of Track and Track Facilities Ukrainian State University of Railway Transport. E-mail: ppx_xiit@kart.edu.ua.

Potapov Dmytro Oleksandrovych, PhD (Tech.), Assistant Professor, Department of Track and Track Facilities,

Ukrainian State University of Railway Transport. E-mail: ppx_xiit@kart.edu.ua.

Malishevska Alina Serhiivna, PhD (Tech.), Assistant Lecturer, Department of Track and Track Facilities, Ukrainian State University of Railway Transport. E-mail: kttolik@gmail.com.

Muryhina Nadiia Oleksandrivna, PhD (Tech.), Assistant Lecturer, Department of Track and Track Facilities, Ukrainian

State University of Railway Transport. E-mail: ppx_xiit@kart.edu.ua.

Статтю прийнято 19.04.2019 р. 